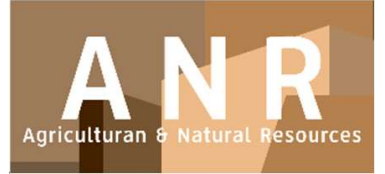

PAPER - OPEN ACCESS

\title{
Isolasi Dan Identifikasi Patogen Yang Menyerang Benih Sengon, Gmelina, Mahoni Dan Tisuk
}

\author{
Author : Nur Hidayati dkk., \\ DOI $\quad: 10.32734 /$ anr.v3i1.828 \\ Electronic ISSN $\quad: 2654-7023$ \\ Print ISSN : :2654-7015
}

Volume 3 Issue 1 - 2020 TALENTA Conference Series: Agriculturan \& Natural Resource (ANR)

\section{(c) $($ i) $\ominus$}

This work is licensed under a Creative Commons Attribution-NoDerivatives 4.0 International License.

Published under licence by TALENTA Publisher, Universitas Sumatera Utara

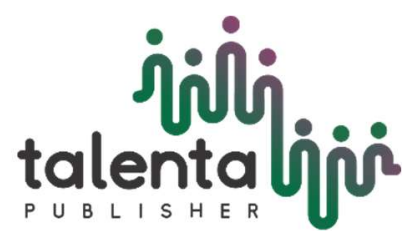




\title{
jibiti talentaliois \\ ANR Conference Series $03(2020)$

\section{Isolasi Dan Identifikasi Patogen Yang Menyerang Benih Sengon, Gmelina, Mahoni Dan Tisuk}

\author{
Nur Hidayati ${ }^{a}$, Siti Husna Nurrohmah ${ }^{a}$, dan Fira Revina ${ }^{b}$ \\ ${ }^{a}$ Balai Besar Penelitian dan Pengembangan Bioteknologi dan Pemuliaan Tanaman Hutan, Jl. Palagan Tentara Pelajar Km. 15 Purwobinangun, \\ Pakem, Sleman, Yogyakarta, Indonesia \\ ${ }^{b}$ Fakultas Biologi, Universitas Jenderal Soedirman Purwokerto, Indonesia
}

Email: inunghidayati@yahoo.com,siti_husna_n@yahoo.com,firarevina@gmail.com

\begin{abstract}
Abstrak
Benih mempunyai peran yang sangat penting dalam pertumbuhan tanaman. Benih dapat dikatakan sehat apabila benih tersebut bebas dari mikroorganisme penyebab penyakit. Adanya patogen yang menginfeksi benih dapat menyebabkan menurunnya kualitas benih. Patogen yang terbawa benih dapat menimbulkan masalah pada benih seperti menurunnya daya kecambah benih serta dapat menyebabkan penyakit pada waktu benih sudah tumbuh menjadi tanaman. Penelitian ini bertujuan untuk mengisolasi dan mengidentifikasi patogen yang menyerang benih tanaman hutan (sengon, gmelina, mahoni dan tisuk). Patogen diisolasi dari benih sengon, mahoni, tisuk dan gmelina yang selama ini disimpan di dalam DCS (Dry Cold Storage), kemudian hasil isolasi diidentifikasi secara mikroskopis dan makroskopis dengan mengamati pertumbuhan dan morfologinya di dalam media buatan. Hasil isolasi dan identifikasi menunjukkan bahwa patogen yang menginfeksi benih sengon, gmelina, mahoni dan tisuk adalah jamur. Jamur Fusarium sp. menyerang benih sengon. Jamur Rhizopus sp. menyerang benih gmelina, jamur Cladosporium sp. menyerang benih mahoni dan tisuk.
\end{abstract}

Kata Kunci: Benih Tanaman Hutan, Patogen, isolasi dan identifikasi

\section{Pendahuluan}

Indonesia memiliki hutan yang sangat luas dan dapat dimanfaatkan untuk pembangunan. Hutan merupakan sumber daya alam yang memiliki banyak manfaat. Sumber daya hutan memiliki manfaat langsung yaitu hasil hutan kayu dan non kayu, pariwisata, pengatur tata air, pencegah erosi, sebagai ekosistem flora dan fauna, dan lain-lain. Benih tanaman hutan memiliki peran yang sangat penting dalam pengembangan hutan tanaman. Tanaman sengon, mahoni, tisuk dan gmelina merupakan beberapa tanaman hutan yang banyak dimanfaatkan untuk berbagai keperluan. Sengon termasuk tumbuhan yang mudah tumbuh. Sengon memiliki manfaat yaitu sebagai bahan bangunan, sebagai reboisasi, bahan kayu bakar, dan penyuburan tanah. Benih sengon termasuk benih dengan kulit biji yang keras. Kerasnya kulit biji merupakan faktor pembatas terhadap masuknya air dan oksigen ke dalam biji. Tanaman mahoni merupakan salah satu tanaman komersil. Kayu tanaman mahoni dapat dijadikan vinir dekoratif dan kayu lapis. Selain itu, dapat pula dipakai untuk meubel, panil, perkapalan, balok percetakan, dan barang kerajinan. Mahoni banyak dijadikan tanaman utama pada areal atau hutan tanaman industri. Jika tanaman mahoni ditanam secara monokultur, maka tegakan mahoni ini menjadi sangat rentan terhadap serangan hama dan penyakit, karena hutan tanaman monokultur merupakan sumber makanan yang berlimpah bagi kedua organisme tersebut [1].

Pohon tisuk merupakan tanaman dari famili Malvaceae. Tisuk digunakan dalam pembangunan hutan tanaman khususnya hutan rakyat. Jenis pohon ini dapat mencapai tinggi $15-25 \mathrm{~m}$ dan diameter batang $15-25 \mathrm{~cm}$, berbatang lurus, tumbuh liar di Jawa Barat dan Jawa Tengah di bawah ketinggian $800 \mathrm{~m}$ di atas permukaan laut dan dapat ditanam hingga $1400 \mathrm{mdpl}$. Tisuk memiliki benih dengan dormansi yang kuat dan sulit untuk dikecambahkan tanpa 
perlakuan skarifikasi. Benih tisuk terdapat dalam kapsul yang dikeluarkan dengan proses penjemuran sehingga buah pecah. Pengeluaran benih yang masih menempel dalam buah secara manual dikeluarkan dengan tangan [2]. Gmelina adalah salah satu tanaman yang mudah tumbuh sehingga dimasukkan dalam tanaman reboisasi. Pemeliharaan gmelina lebih mudah dan cepat tumbuh sehingga menjadi pilihan tanaman perkotaan. Gmelina umur 10-15 tahun sudah bisa dipanen untuk kayu bakar, bahan bangunan, dan sebagai bahan gergajian. Sumber bibit bisa dari Generatif atau vegetatif (stek) dengan jarak tanam $3 \mathrm{~m}$ x $3 \mathrm{~m}$ [3].

Penyakit tanaman dapat terjadi karena pada suatu waktu di satu tempat terdapat tanaman yang rentan, patogen yang virulen, dan faktor lingkungan dapat mempengaruhi timbul dan berkembangnya suatu penyakit. Faktor ini memberikan pengaruh terhadap pertumbuhan tanaman inang dengan menciptakan kondisi yang sesuai bagi kehidupan jenis patogen tertentu. Beratnya intensitas penyakit pada suatu tanaman seringkali ditentukan oleh lamanya keadaan lingkungan yang menguntungkan untuk timbul dan berkembangnya penyakit. Pengaruh dari tanaman inang terhadap timbulnya suatu penyakit tergantung dari jenis tanaman inang, kerentanan tanaman, bentuk dan tingkat pertumbuhan, kerapatan, kesehatan tanaman, dan ketahanan inang [4]. Patogen dapat ditemukan pada benih atau tanaman propagative seperti umbi-umbian dan parasit. Benih adalah biji tanaman yang tumbuh menjadi tanaman muda (bibit), kemudian dewasa dan menghasilkan bunga. Benih sangat berpotensi sebagai wahana pembawa hama dan penyakit tanaman. Penyakit benih telah menyerang hampir sebagian benih tanaman. Terdapat ratusan cendawan patogen penting pada tanaman merupakan patogen tular benih. Fungi yang menyerang benih menyebabkan menurunnya mutu benih. Selain itu, benih yang mengalami masa simpan dalam kondisi benih atau lingkungan simpan yang tidak optimum viabilitasnya akan turun yang ditunjukkan oleh turunnya daya berkecambah benih [5].

Jenis penyakit yang sering di temukan pada benih yaitu penyakit lodoh (Dumping-off). Penyakit tersebut merupakan suatu penyakit yang disebabkan oleh fungi seperti Pythium, Fusarium, Phytophthora, Aspergillus, Penicillium, Cladosporium, dan Rhizoctonia yang dapat menyerang benih tanaman termasuk menyerang tanaman hutan. Fungi merupakan mikrorganisme yang mempunyai dinding sel, umumnya tidak bergerak, tidak mempunyai klorofil, serta tidak mampu melakukan proses fotosintesis atau menghasilkan bahan organik dari karbondioksida dan air [6]. Adanya hama dan penyakit pada benih akan mempengaruhi kualitas benih. Jenis patogen yang menginfeksi benih yaitu dapat berupa cendawan, bakteri, dan virus, yang dapat menimbulkan penyakit pada benih. Oleh karena itu, identifikasi hama dan penyakit pada benih sangat perlu untuk dilakukan. Setelah jamur diisolasi dan diidentifikasi maka dapat diamati lebih lanjut tentang patogen penyebab penyakit pada tanaman tersebut [7]. Tujuan daripada penelitian ini adalah isolasi dan identifikasi patogen yang menyerang benih tanaman hutan (sengon, mahoni, tisuk dan gmelina).

\section{Bahan dan Metode}

\subsection{Waktu dan Lokasi}

Penelitian dilakukan pada bulan Januari sampai dengan bulan Februari 2019. Penelitian dilaksanakan Laboratorium Hama dan Penyakit, Balai Besar Penelitian dan Pengembangan Bioteknologi dan Pemuliaan Tanaman Hutan, Yogyakarta.

\subsection{Bahan dan Alat}

Alat yang digunakan dalam penelitian ini adalah object glass, cover glass, timbangan analitik, label, cawan petri, pinset, scalpel, tissue, autoklaf, kamera, mikropipet, gelas ukur, botol, bunsen, plastik wrap, alumunium foil, LAF, masker, botol kultur, batang drugalsky, kain saring, korek api, penjepit, mikrotube, mikroskop, haemositometer, alat tulis, botol duran, lemari pendingin, dan sprayer. Bahan yang digunakan adalah benih-benih tanaman hutan yang terdiri dari sengon, mahoni, tisuk, gmelina, air steril, Potato Dextrose Agar (PDA) bubuk, spora jamur, akuades steril, alkohol, bayclin, lactopenol blue, safranin, dan desinfektan. 


\subsection{Prosedur Kerja}

\subsubsection{Sterilisasi Alat dan Bahan}

Alat-alat yang akan digunakan disterilisasi di dalam autoklaf dengan suhu $121{ }^{\circ} \mathrm{C}$ dan tekanan 2 atm selama 30 menit. Media PDA (Potato Dextrose Agar) sebanyak 39 gr ditambah $1000 \mathrm{~mL}$ akuades steril disterilisasi dalam autoclaf selama 20 menit pada suhu $121^{\circ} \mathrm{C}$ dan tekanan $1 \mathrm{~atm}$.

\subsubsection{Isolasi}

Isolasi dilakukan pada benih sengon, gmelina, mahoni dan tisuk masing-masing sebanyak 3 ulangan dengan meletakkannya sebanyak 4 materi tanam di media PDA yang telah disiapkan. Subkultur dilakukan untuk memindahkan miselium jamur yang tumbuh pada masing-masing media tanam pada media PDA, sehingga diperoleh biakan murni.

\subsubsection{Identifikasi Jamur}

Hasil pengamatan mikroskop pada preparat yang telah diamati diidentifikasi dengan cara membandingkan hasil pengamatan dengan buku referensi.

\subsubsection{Penghitungan spora jamur}

Penghitungan jumlah spora dilakukan setelah sebelumnya dilakukan pemanenan spora. Cara pemanenan yaitu dengan spora jamur dalam media dikerok secara tipis kemudian bersama dengan media dalam cawan petri tersebut dipotong kecil-kecil. Campuran kerokan spora dan media tersebut dimasukkan ke dalam botol kultur yang berisi air steril $30 \mathrm{ml}$ dan dikocok sampai spora jamur terlepas dari media. Kemudian botol steril kosong disiapkan dan letakkan kain saring di atas mulut botol. Campuran hasil panen spora dalam botol disaring, masukkan ke botol kultur tersebut dan dikocok. Ini dilakukan untuk mendapatkan larutan induk [8]. Larutan induk diambil dengan menggunakan mikropipet ukuran $50 \mu 1$ kemudian dimasukkan ke mikrotube ukuran 1,5 $\mu 1$. Sebanyak $50 \mu$ l pewarna lactophenol blue dimasukkan ke dalam mikrotube tersebut. Cairan dalam mikropipet diambil sebanyak $16 \mu \mathrm{L}$ dimasukkan ke haemocytometer. Kemudian pengamatan dan penghitungan jumlah spora dilakukan di bawah mikroskop.

\subsubsection{Inokulasi}

Hasil suspensi dari panen spora yang sudah didinginkan dimasukkan semua dalam sprayer. Cairan dalam sprayer disemprotkan ke masing-masing benih yang telah disiapkan dalam cawan petri kemudian ditutup.

\subsubsection{Reisolasi}

Reisolasi dilakukan dengan mengisolasi jamur dari benih-benih yang telah diinokulasi. Benih-benih direisolasi masing-masing dengan 3 ulangan. Tujuan reisolasi yaitu untuk mengetahui isolat jamur yang tumbuh sama atau tidaknya dengan jamur awal hasil isolasi. Reisolasi dilakukan sebagai uji Postulat Koch untuk pembuktian bahwa isolat fungi yang ditemukan merupakan penyebab utama penyakit pada masing-masing benih [9].

\section{Hasil dan Pembahasan}

\subsection{Isolasi Benih}

Benih adalah biji tanaman yang tumbuh menjadi tanaman muda (bibit) kemudian dewasa dan menghasilkan bunga. Penyakit benih telah menyerang hampir sebagian benih tanaman. Isolasi pada benih dilakukan untuk mengetahui penyakit pada benih khususnya benih tanaman hutan yang telah lama disimpan [10]. 

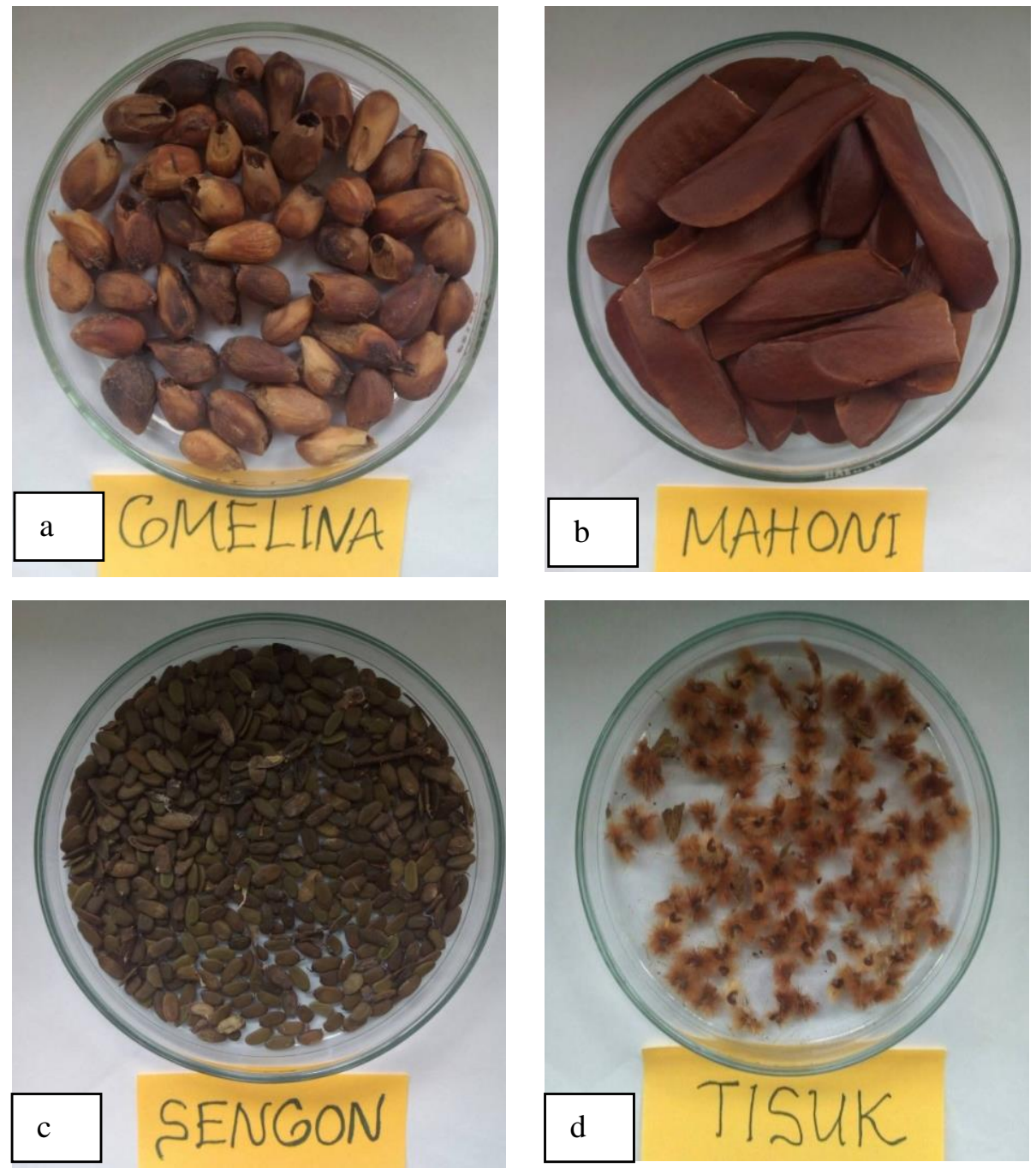

Gambar 1. a. Benih Gmelina b. Benih Mahoni c. Benih Sengon d. Benih Tisuk

Isolasi adalah proses pemisahan mikroorganisme yang diinginkan dari populasi campuran ke media biakan (buatan) untuk mendapatkan kultur murni. Tujuan isolasi adalah untuk mendapatkan kultur murni dari jamur yang menyerang benih-benih tersebut. Isolasi dilakukan dengan memilih benih-benih yang terlihat kotor atau jelek kemudian ditanam di media PDA yang telah disiapkan [11]. Sub kultur benih dilakukan setelah tahapan isolasi benih berhasil. Sub kultur dilakukan pada benih yang telah ditumbuhi miselium jamur yang jernih, bebas dari kontaminan, dan berasal dari benih itu sendiri. Teknik sub kultur adalah teknik untuk memindahkan biakan mikroorganisme dari satu medium ke medium lainnya. Sub kultur berfungsi memindahkan biakan ketika media telah terindikasi kehabisan nutrisi setelah beberapa waktu ditumbuhi mikroorganisme. Sub kultur dilakukan di Laminar Air Flow kemudian hasilnya disimpan pada suhu ruang untuk kemudian diamati setiap harinya [12]. 


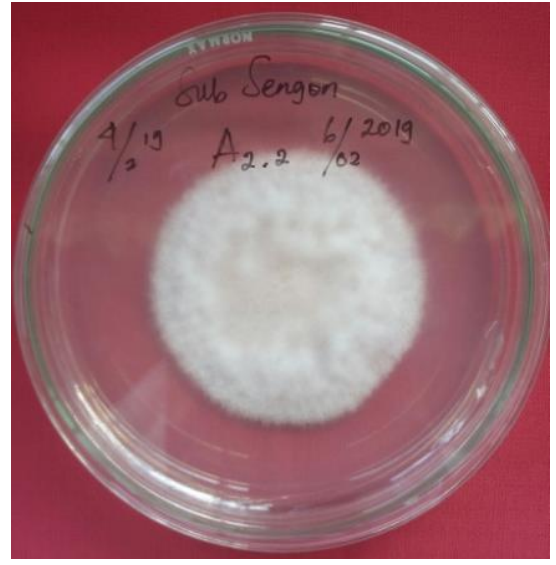

(a)

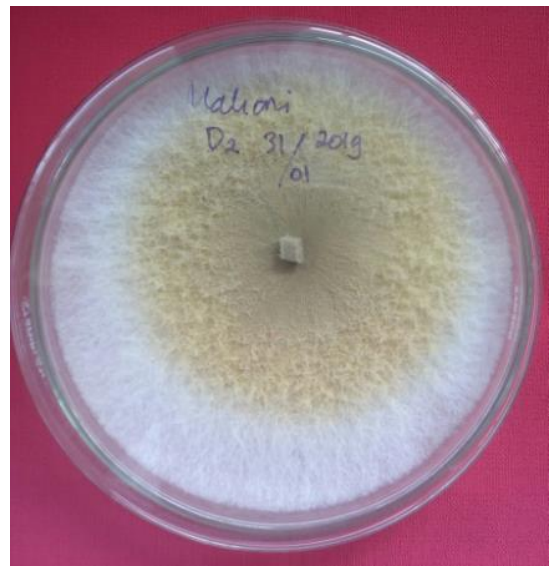

(c)

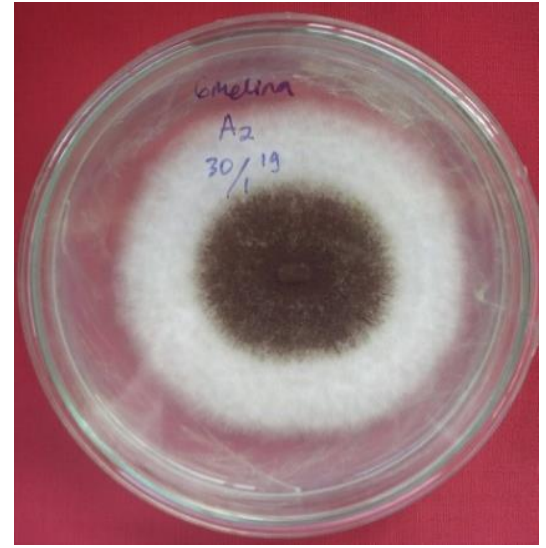

(b)

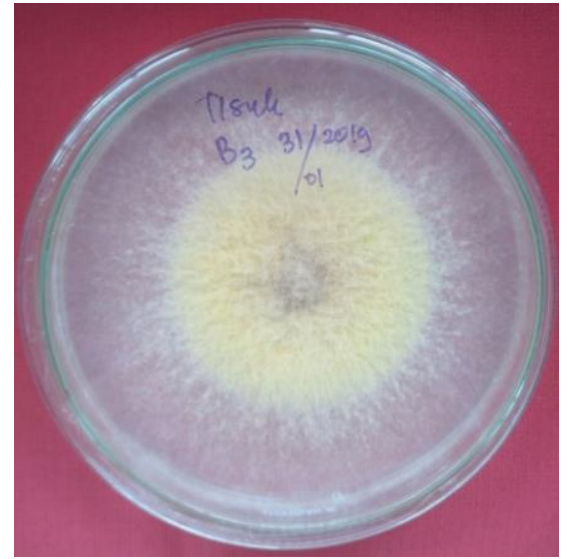

(d)

Gambar 2. Isolat jamur pada hari ke-14 yang diisolasi dari benih a. Sengon, b. Gmelina c. Mahoni, d. Tisuk

\subsection{Pengamatan Morfologi Isolat dan Mikroskopik}

Isolat jamur diamati secara makroskopis dan mikroskopis. Jamur dalam cawan petri diamati pertumbuhannya selama 14 hari. Deskripsi morfologi meliputi pengamatan secara makroskopik dan mikroskopik. Pengamatan makroskopik untuk melihat morfologi isolat dari awal pertumbuhan hingga pertumbuhan hari ke-14 yang meliputi bentuk dan permukaan koloni, warna koloni, pola penyebaran koloni, dan tepi koloni. Deskripsi mikroskopik dilakukan untuk mengamati bentuk hifa dan bentuk spora (spora aseksual). Pengamatan mikroskopis dilakukan dengan menggunakan pewarnaan laktofenol yang kemudian diamati di bawah mikroskop. Identifikasi dilakukan dengan mengamati ciri morfologi isolat jamur yang tumbuh dalam cawan petri [13]. Morfologi jamur yang menyerang benih tanaman sengon yaitu terlihat miselium jamur berwarna putih kemerahan. Tekstur miselium tampak seperti kapas. Jika cawan petri dibalik dapat dilihat bahwa warna putih kemerahan tampak di tengah-tengah koloni dan menyebar. Warna permukaan koloni dan sebalik koloni terlihat hampir sama. Hal tersebut sesuai dengan pustaka yang menyatakan bahwa isolat jamur yang menyerang benih sengon koloninya berwarna putih disertai warna ungu atau merah pada pusat koloninya [14]. Isolat yang dipakai untuk pengamatan secara mikroskopik adalah isolat jamur yang berumur 14 hari. Spora jamur yang menyerang benih tanaman sengon yaitu berbentuk seperti bulan sabit. Spora tersebut di dalamnya terdapat garis-garis seperti sekat. Penampakan pada mikroskop lebih sering terlihat bahwa letak antara spora satu dan spora lainnya saling terpisah atau berjauhan. Spora tersebut seperti makrokonidia yang mempunyai bentuk khas yaitu seperti bulan sabit, terdiri dari 3-5 septa, dan berwarna hialin [9]. 


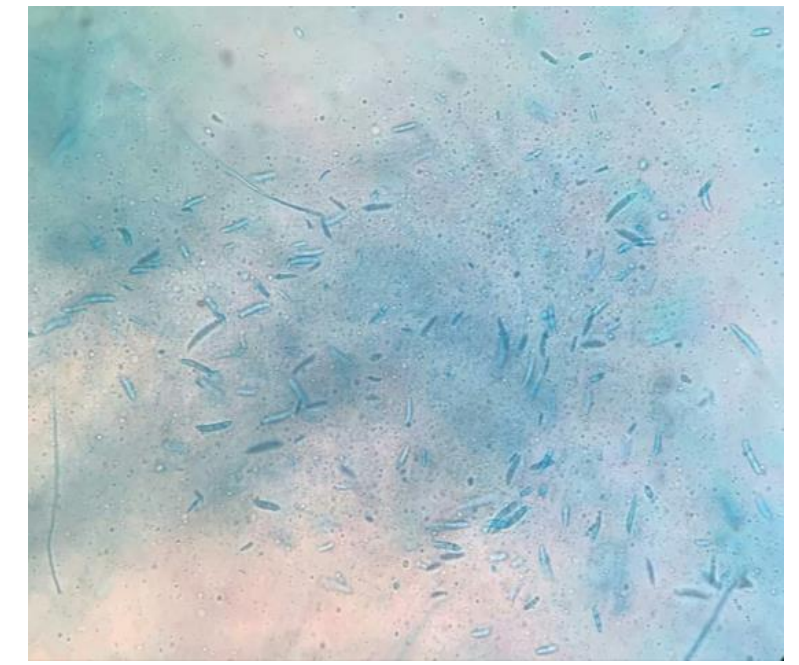

Gambar 3. Spora jamur yang menyerang benih sengon (Perbesaran 40x)

Isolat jamur yang menyerang benih Gmelina terlihat pusat koloninya berwarna hitam dan ujung koloni berwarna putih. Ujung koloninya seperti benang-benang halus. Tipe penyebarannya konsentris. Pertumbuhannya tidak terlalu cepat karena sampai hari ke 14 isolat tersebut tidak memenuhi cawan secara penuh. Penampakan mikromorfologinya terlihat kantong spora yang berisi banyak spora dan terdapat tangkainya. Tangkai kantong spora tersebut dapat tunggal maupun bercabang. Berdasarkan pengamatan tampak talus miseliumnya berkembang dengan baik. Hifa fertil menghasilkan sporangium pada ujung sporangiofora. Hifa seperti akar yang pendek dan bercabang banyak (rhizoid) terlihat disamping hifa vegetatif. Rhizoid digunakan untuk menempel ke substrat [15].

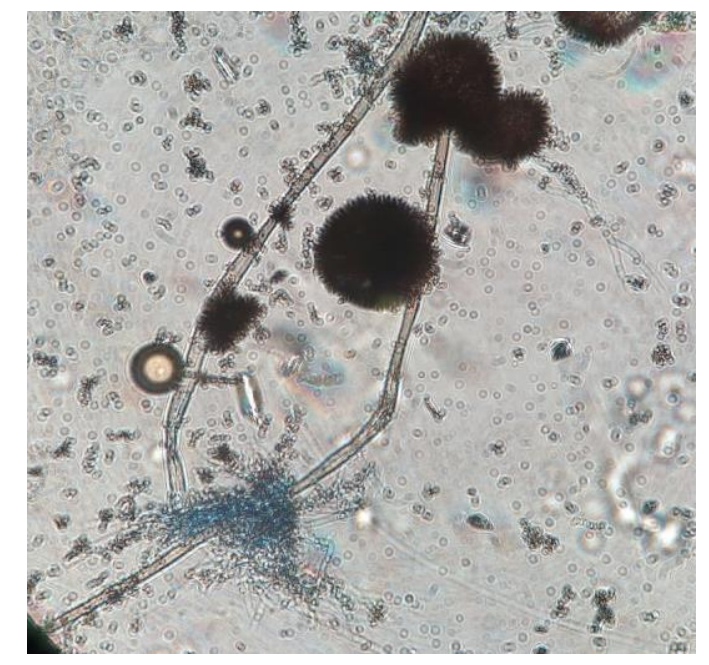

Gambar 4. Spora Jamur pada Benih Gmelina (Perbesaran 40x)

Morfologi isolat jamur yang menyerang benih mahoni hampir sama dengan isolat jamur yang menyerang benih tisuk. Isolat jamur tersebut menunjukkan koloni dengan warna kuning dan ujungnya berwarna putih. Miseliumnya terlihat seperti keriting bertumpuk. Koloni tumbuh dengan cepat hampir memenuhi cawan petri pada hari ke 14. Isolat tersebut menimbulkan bau yang tidak sedap. Pusat koloni terlihat berwarna kuning sedikit kehijauan. Penampakan mikromorfologi diamati di mikroskop dengan pewarna safranin. Pada pengamatan mikroskop terlihat spora yang berbentuk bulat lonjong. Selain itu, terlihat spora berbentuk oval atau elips. Spora tersebut ada yang tunggal atau berdiri sendiri adapula yang berderet memanjang, dan adapula yang bergerombol. Kantung spora yang berisi banyak spora terlihat pada isolat benih tisuk dan mahoni [1]. 

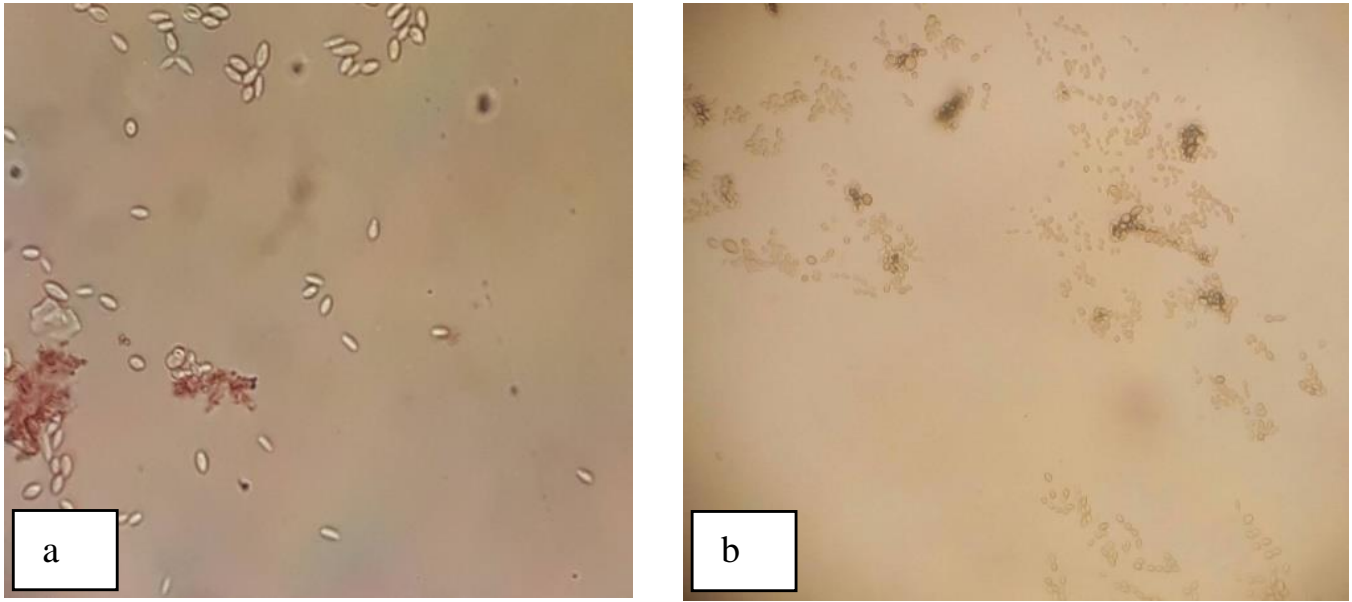

Gambar 5. (a). Spora jamur pada pada benih Mahoni (b). Spora jamur pada benih Tisuk (Perbesaran 40x)

\subsection{Inokulasi jamur hasil Isolasi}

Sisa cairan hasil panen spora (suspensi) dalam botol kultur dimasukkan ke dalam sprayer kemudian disemprot ke masing-masing benih yang baru. Benih-benih yang terlihat sehat dipilih. Lalu, benih-benih tersebut diletakkan pada masing-masing cawan petri yang telah dilapisi tissue. Benih-benih tersebut diamati tiap harinya setelah disemprot spora. Konsentrasi jamur yang diinokulasi pada benih sebanyak $10^{3} \mathrm{spora} / \mathrm{ml}$. Teknik inokulasi spora dapat dilakukan dengan teknik spray. Pengamatan gejala dan tanda pada benih dilakukan pada hari ke 1, 2, 3, dan 4 setelah inokulasi [16].

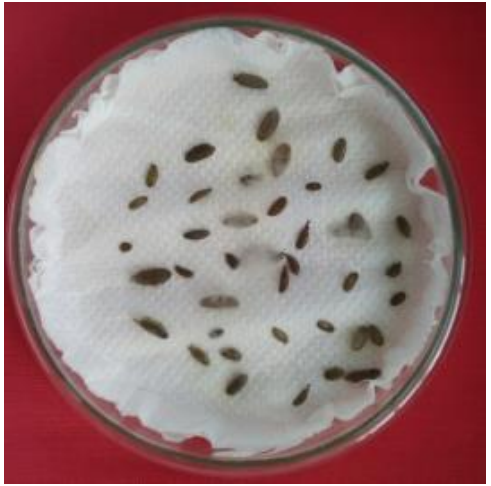

(a)

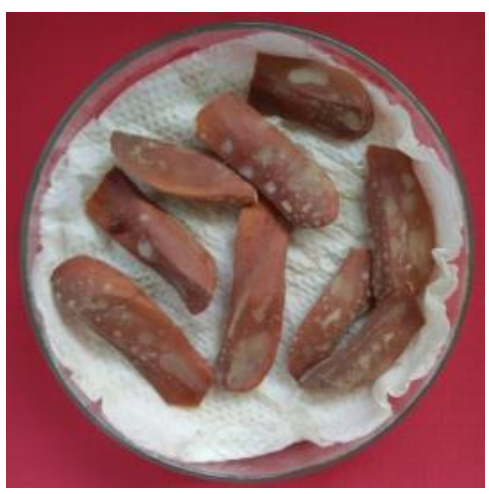

(c)

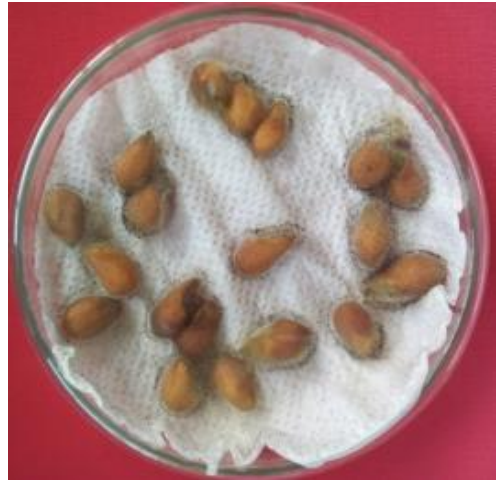

(b)

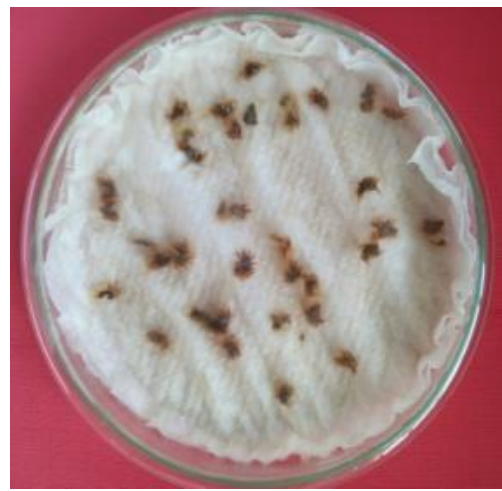

(d) 
Berbagai gejala akibat patogen dapat ditimbulkan baik pada satu spesies tumbuhan atau pada spesies yang berbeda. Gejala yang sama dapat pula ditimbulkan dari patogen yang berbeda. Gejala (symptom) adalah ekspresi dari inang terhadap kondisi penyakit patologik sehingga suatu penyakit tertentu dapat dibedakan dengan penyakit lain. Gejala selalu berubah dengan berkembangnya penyakit. Tanda (sign) yaitu struktur dari suatu patogen yang berasosiasi dengan tubuh tanaman atau bagian tanaman yang terinfeksi berupa adanya benda-benda atau alat-alat tubuh dan alatalat pembiakan dari patogen atau parasit penyebabnya. Contoh tanda yaitu berupa miselium, spora, tubuh buah jamur, dan sel atau lendir bakteri [17].

\subsection{Identifikasi Jamur}

Identifikasi jamur dilakukan berdasarkan karakter morfogi isolat jamur baik secara makroskopis maupun mikroskopis. Isolat jamur yang diperoleh berdasarkan karakter makromorfologi dan mikromorfologi dibandingkan dengan berbagai jurnal penelitian ilmiah dan buku referensi yang berkaitan dengan jamur yang menyerang benih tanaman. Dari hasil isolasi jamur dari berbagai macam benih, dapat diketahui bahwa bahwa jamur yang menyerang benih tanaman sengon yaitu Fusarium sp., pada benih gmelina adalah Rhizopus sp., serta jamur Cladosporium sp. menyerang benih mahoni dan tisuk [18]. Jamur ini menghasilkan tiga jenis spora yaitu mikrokonidia, makrokonidia, dan klamidospora. Mikrokonidia berbentuk oval, bersel satu, dan hialin. Mikrospora umumnya terbentuk pada saat patogen berada dalam pembuluh inang. Mikrokonidia merupakan struktur yang paling banyak dibentuk oleh Fusarium sp. dalam berbagai lingkungan. Makrokonidia mempunyai bentuk yang khas yaitu seperti bulan sabit, terdiri dari 3-5 septa dan berwarna hialin. Miselium fungi bersepta dan bercabang-cabang dengan warna hialin. Berdasarkan praktik kerja lapangan pada isolat jamur secara mikroskopis hanya terlihat makrokonidia yang berbentuk seperti bulan sabit. Makrokonidia tersebut merupakan ciri khas dari jamur Fusarium sp. [9].

Isolat jamur yang menyerang benih gmelina dapat diketahui yaitu Rhizopus sp. Jamur Rhizopus sp. memiliki sporangiospora berwarna hitam kecokelatan, warna miseliumnya putih, tekstur sporangiosfor halus, dan terdapat tangkai spora. Hal tersebut sesuai dengan jurnal ilmiah yang menyatakan bahwa Rhizopus sp. memiliki stolon dan rhizoid yang warnanya gelap jika sudah tua, sporangiofora tumbuh pada noda tempat terbentuk juga rhizoid, sporangia besar dann berwarna hitam, dan pertumbuhannya cepat. Jamur Rhizopus sp. selain ditemukan pada benih dapat pula ditemukan di tempe [19]. Rhizopus sp. memiliki sifat saprofit dan sporangiumnya disertai dengan sporangiospora berwarna hitam bulat. Rhizopus sp. termasuk ke dalam kelas Zygomycetes yang dapat berkembang biak secara aseksual dengan menghasilkan sporangium dan juga dapat membentuk klamidospora. Klamidospora adalah spora yang berdinding tebal yang juga digunakan sebagai alat untuk mempertahankan diri pada kondisi tidak menguntungkan. Rhizopus sp. ini juga bisa mengalami pembiakan secara seksual yaitu dengan gametangiogami yang menghasilkan zigospora [20].

Identifikasi pada isolat jamur pada benih mahoni dan tisuk diketahui yaitu jamur Cladosporium sp. yang menyerang benih tersebut. Berdasarkan ciri-ciri mikromorfologi kedua isolat jamur tersebut sama-sama menunjukkan ciri seperti jamur Cladosporium sp.. Akan tetapi, penampakan secara langsung pada isolat jamur di cawan petri keduanya tidak sepenuhnya mirip. Perbedaannya dapat dilihat pada warna isolat. Warna isolat jamur dari benih mahoni terdapat warna kuning kehijauan pada pusat miseliumnya. Sedangkan, isolat benih tisuk terdapat warna kuning cerah pada pusat miseliumnya. Hal tersebut menunjukkan bisa jadi satu jamur yang sama, tetapi dengan spesies yang berbeda. Oleh karena itu, untuk mengetahui secara lanjut terkait Cladosporium sp. yang menyerang benih perlu dilakukan identifikasi dan klasifikasi yang lebih mendalam. Cladosporium sp. adalah jamur yang memiliki konidiofor, ramokonidia, hifa, dan konidia berantai. Hasil pengamatan karakter morfologi cendawan Cladosporium sp. memiliki sifat koloni berkapas dan warna khas bagian dasar hitam keabuan. Isolat jamur secara mikroskopik terlihat jamur tersebut memiliki konidia berantai panjang. Cladosporium sp. juga ditemukan pada tanaman hias, tanaman hutan, tanaman padi, dan tomat. Akibat yang ditimbulkan dari serangan jamur Cladosporium sp. pada benih adalah menimbulkan perubahan warna, bau apek, pembusukan, perubahan komposisi kimia, peningkatan kadar asam lemak, dan penurunan kandungan nutrisi dan akhirnya mengakibatkan penurunan daya kecambah. Benih mahoni yang terinfeksi cendawan terlihat mengalami perubahan warna serta berbau apek, hal ini disebabkan adanya pembusukan akibat serangan cendawan [21]. 


\section{Ucapan Terima Kasih}

Penelitian dilakukan dengan dana DIPA Balai Besar Penelitian dan Pengembangan Bioteknologi dan Pemuliaan Tanaman Hutan (BBPPBPTH). Terima kasih penulis sampaikan kepada semua pihak yang telah membantu dalam pelaksanaan penelitian dan penyediaan referensi dalam penulisan naskah.

\section{Referensi}

[1] Darmuh, S., Arif, A., dan Taskirawati, I. (2018) “Keragaman Jenis Jamur yang Menyerang Tanaman Mahoni (Swietenia macrophylla King.) di Kampus Universitas Hasanuddin Makassar, Sulawesi Selatan.” Jurnal Perennial 14 (1): 9-16.

[2] Yuniarti, N. dan Pramono A. (2013) "Upaya Mempercepat Perkecambahan Benih-Benih Dorman Untuk Menunjang Keberhasilan Penanaman Hutan", in Prosiding Seminar Nasional Silvikultur I dan Pertemuan Ilmiah Tahunan Masyarakat Silvikultur Indonesia, Makassar

[3] Sandalayuk, D., Simarangkir, B.D.A.S., Lahjie, A., dan Ruslim, Y. (2018) "Analisis Pertumbuhan Gmelina (Gmelina alborea.Roxb) dan Mahoni (Swietenia magrophylla King) di Gorontalo.” Journal of Forestry Research 1 (1): 1-8.

[4] Blanchard, R.O dan Tattar, T.A. (1981) "Field and Laboratory Guide to Tree Pathology", New York, Academic press

[5] Permana, N. D. dan Rustiani, U.S. (2017) "Modul Identifikasi Cendawan Penyebab Penyakit Tanaman", Yogyakarta, Deepublish

[6] Robinson, R. (2001) "Biology Macmillan Science Library”, USA, Macmillan

[7] Yuniarti, N., Suharti, T., dan Rustam, E. (2015) "Identifikasi Hama dan Penyakit Benih Nyamplung (Callophyllum inophyllum) di Carita, Ciamis, Cilacap, Purworejo, Gunung Kidul, Alas Purwo, Lombok, dan Pariaman.” Pros Sem Nas Masy Biodiv Indon 1 (6): $1442-1447$.

[8] Sudantha, M., Stella, P. T. R., Jayadi, I. (2018) "Produksi dan Penerapan Teknologi Hayati (Biokompos, Bioaktivator, dan Bibit Unggul Bawang Merah) pada Budidaya Tanaman Bawang Merah.” Jurnal Abdi Insani Unram 5 (2): 18-27.

[9] Nuraeni, Y., Anggraeni, I., dan Dwi, R.M. (2018) “Identifikasi Penyakit Layu pada Bibit Gmelina (Gmelina arborea Roxb.) di Persemaian dan Uji Antagonisme Trichoderma sp. Secara In Vitro.” Jurnal Sains Natural 8 (2): 50-58.

[10] Dewi, P.N. dan Salamah, R.U. (2017) "Identifikasi Cendawan Penyebab Penyakit Tanaman”, Yogyakarta, Deepublish

[11] Perhutani (1999) “Selayang Pandang Persemaian Permanen Pongpoklandak KPH Cianjur”, Cianjur, Perum Perhutani Unit III Jawa Barat KPH Cianjur

[12] Ratulangi, M. M., Sembel, D. T., Rante, C. S., Dien, M. F., Meray, E. R. M., Hammig, M., Shepard, M., Carner, G., dan Benson, E. (2012) "Diagnosis dan Insidensi Penyakit Antraknosa pada Beberapa Varietas Tanaman Cabe di Kota Bitung dan Kabupaten Minahasa." Jurnal Eugenia 18 (2): 81-90.

[13] Nuryadi, H. W., Rakhmawati, A., dan Prihatini, I. (2016) "Isolasi dan Identifikasi Kapang Endofit dari Pohon Sengon Provenan Kepulauan Solomon Berdasarkan Morfologi dan Molekuler (Analisis Rdna Its (Internal Transcribed Spacer).” Jurnal Biologi 5 (6): $15-27$.

[14] Mahendra, S.A., Priyatmojo, A., dan Wibowo, W. (2008) “Identifikasi Morfologi Beberapa Spesies Jamur Fusarium.” Jurnal Perlindungan Tanaman Indonesia 14 (1): 7-13.

[15] Pelczar, Michael, J., dan Chan, E.C.S. (1986) “Dasar-Dasar Mikrobiologi”, Jakarta, UI-Press

[16] Zainudin, Latief, A.A., dan Qurata, A.L. (2014) "Pengaruh Pemberian Plant Growth Promoting Rhizobacteria (Bacillus subtilis dan Pseudomonas fluorescens) terhadap Penyakit Bulai pada Tanaman Jagung (Zea mays L.).” Jurnal HPT 2 (1): 11-18.

[17] Chatri, M. (2016) "Pengantar Ilmu Penyakit Tumbuhan", Jakarta, Kencana

[18] Barnet, H.L., dan Hunter, B.B. (2006) "No Title Ilustrated Genera of Imperfect Fungi (4th ed.)", Australia, The American Phytopathological Society St. Paul, Minnesota

[19] Stia, D.R. dan Aziz, S. (2011) “Identifikasi Rhizopus oligosporus pada Beberapa Inokulum Tempe di Kabupaten Banyumas.” Jurnal Molekul 6 (2): 93-104.

[20] Herliyana. E.N. (2009) “Identifikasi Jamur Mold dan Blue Stain pada Rotan.” Jurnal Ilmu dan Teknologi Hasil Hutan 2 (1): $21-26$.

[21] Purwaka, P.K., Bramasto, Y., dan Suharti, T. (2011) “Benih Mahoni (King) pada Berbagai Kondisi dan waktu Simpan.” Jurnal Tekno Hutan Tanaman 4 (1): 1-6. 